\title{
Strategies to Improve Children's Interest in Reading Activities
}

Diana-Crina Marin, Mușata Bocoș 


\title{
Strategies to Improve Children's Interest in Reading Activities
}

\author{
Diana-Crina Marin ${ }^{a}$, Mușata Bocoș ${ }^{b}$ \\ a Doctoral School "Education, Reflection, Development”, Babes-Bolyai University Cluj-Napoca, 7 Sindicatelor Street, 400029, Romania \\ ${ }^{b}$ Babes-Bolyai University, Faculty of Psychology and Educational Sciences, 7 Sindicatelor Street, 400029, Cluj-Napoca, Romania
}

*Corresponding author: crinadiana88@yahoo.com

\section{Abstract}

\section{Keywords:}

Reading habits; primary school; educational partnership; efficient strategies; interactive learning.
Through this study, we aimed to establish which are the main strategies that teachers use to increase pupils' interest in reading activities. It is unanimously accepted that frequent reading of texts has a beneficial effect on the harmonious development of each pupil. In order to create an inventory of examples of good practices provided by teachers for primary education, an online questionnaire was administered between June and October 2020. 219 teachers have completed the questionnaire and mentioned which strategies they use most frequently to make pupils appreciate the value of the books and to read more frequently. The study revealed several good practices that can be used by teachers or parents to motivate pupils to be more actively engaged in reading activities. These results are useful for primary school teachers who can use them to improve the strategies they use to determine pupils to read more frequently and with pleasure. Working with the books, frequent presentation of the content of some books, organizing reading clubs, visiting the school library, arranging a reading corner, and making portfolios about the content of favorite books are some of the strategies mentioned by teachers.

\section{Zusammenfasung}

\section{Schlüsselworte:}

Lektüreangewohnheit; Grundschule;

Ausbildungspartnerschaft; wirksame Strategien; interaktives Lernen.
Durch diese Studie nahmen wir uns vor, die wichtigsten Strategien zu identifizieren, welche die Lehrer für den Primärunterricht benutzen, damit die Schüler sich für die Lektüre mehr interessieren. Man geht einstimmig davon aus, dass das regelmässige Lesen bestimmter Texte sich günstig auf die harmonische Entwicklung der Kleinen auswirkt. Um die Beispiele bezüglich der guten Vorgänge der Lehrer vom Primärunterricht hervorzuheben, wurde ein Online-Fragebogen im Zeitraum Juni-Oktober 2020 benutzt. 219 Lehrer füllten diesen Online- Fragebogen aus und erwähnten, welche Strategien sie am meisten benutzen, damit die Schüler die Bücher schätzen und häufig lesen. Die Studie zeigte eine Reihe von Gebräuchen, die von den Lehrern oder von den Eltern benutzt werden können, damit die Schüler die Lektüre lieben. Diese Ergebnisse sind den Lehrern für den Primärunterricht nützlich und man kann sie verwerten, um die von ihnen benutzten Strategien, damit die Schüler häufiger und gern lesen, zu verbessern. Die Arbeit mit dem Buch, die häufige Darstellung des Inhalts bestimmter Bücher, die Veranstaltung der Lektüreclubs, die Besichtigung der Schulbibliothek, die Einrichtung eines Lektüreraums und die Erstellung eines Portfolios über den Inhalt der Lieblingsbücher zählen zu den Strategien, die am meisten von den Lehrern benutzt werden.

\section{Introduction}

Frequent reading of age-appropriate books contributes significantly to optimizing the school results of the pupils. Most of the pupils allocate very little time to do reading activities. Starting from the premise that if we use effective strategies that were recommended by a large number of teachers, will increase pupils' interest in reading, we have conducted a study that aimed to collect information on how teachers determine pupils to read. The benefits of frequent book reading are unanimously accepted. Frequent use of new technologies and the high quantity of time allocated to use electronic devices with the visual display are factors that can influence in a negative way the pupils' level of interest in reading. The main challenge encountered in developing pupils' interest in reading activities is related to the absence of desire to read books, even if the books are appropriate to their age.

\section{Theoretical foundation}

The reading abilities of the children and their interest in reading are developed during the primary school cycle. Strategies used in the classroom by the teacher can influence the well-being of pupils and their decisions regarding the learning processes or reading habits (Chu, $\mathrm{Li} \& \mathrm{Yu}, 2020$ ). Teachers make systematic efforts to develop pupils' interest in reading. Visits to libraries are some of the most frequently used strategies to familiarize children with reading (Gong, 2016). Some researchers have shown that pupils will enjoy reading if they do these activities in the company of colleagues, family members, and even in the 
presence of pets. Developing correct reading and writing skills is an extremely complex process (Johnston \& Watson, 1997). Pupils' performance in reading processes, during first grade, can be an important predictor of pupils' interest in reading activities, but other factors can influence significantly the motivation of the pupils to perform such activities (Kirby, Ball, Geier, Parrila \& Wade-Woolley, 2010). Identifying optimal strategies to stimulate and sustain pupils' interest in reading activities has beneficial effects and is not always a simple process (Mathison, 1989). Also, some pupils read frequently, while others read less often.

Understanding the reading habits of the children and their attitudes has a positive impact on teachers' work. Gender differences and the reading habits of family members are factors that can influence children's interest in reading (Mostert \& Wikan, G, 2008, Rasinski, 1991; Uusen, \& Müürsepp, 2012). Digital resources can be also used to increase pupils' interest in reading activities (Narulita Mahendra, 2020). Books in electronic format are considered attractive by some of the pupils. Stimulating children's interest in reading activities should start at an early age. Also, children's interest in reading is closely related to the positive parenting practices adopted by parents. (Pezoa, Mendive \& Strasser, 2019). Knowing a large variety of examples of good practices that were applied in classroom activities or during programs organized with the purpose to stimulate children's interest in reading can help us to improve our teaching strategies (Sánchez, Campillo \& Díaz, 2020). Activities such as writing, cooperative learning, or frequent reading have a positive impact on pupils' creative thinking (Segundo Marcos, López Fernández, Daza González \& Phillips-Silver, 2020). Reading aloud by parents each day has beneficial effects on children's development (Zivan \& Horowitz-Kraus, 2020).

\section{Research methodology}

To conduct this research, an online questionnaire was created. The questionnaire was distributed in the online environment and was completed by 219 teachers. The content of the questionnaire is included in Annex A. Through this study, we aimed to find the answer to the following questions:

- How often are pupils involved in reading activities?

- What can teachers and parents do to increase pupils' interest in reading activities?

\section{Results}

Most of the teachers who have decided to fill in the questionnaire work with pupils enrolled in the third grade (54 respondents). Also, a large number of respondents work with children from the first grade or the second grade (see figure 1).

Figure 1. The description of the sample of the respondents

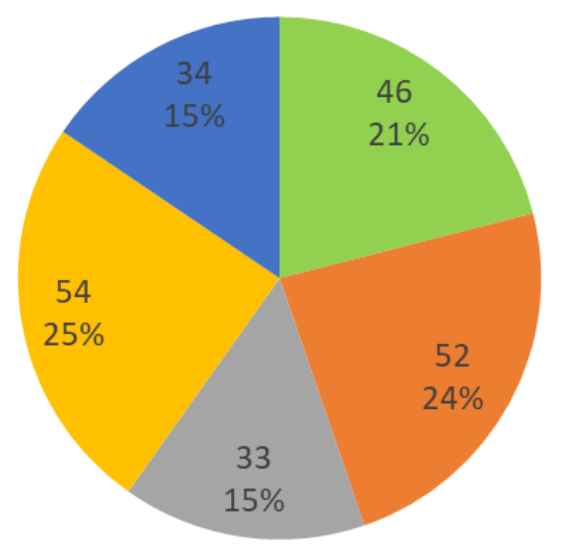

- Preparatory grade $\square$ 1st grade $\square$ 2nd grade $\square$ 3rd grade $\quad$ 4th grade

Most teachers appreciated the fact that the school library contains age-appropriate books for primary school students. 119 of them selected the affirmative answer to the second question of the questionnaire: "Do you think that the school library has enough books for primary school pupils?". A part of the respondents considered that the school library is not well equipped with new books. Some of the respondents showed that there is no library inside the school (see figure 2).

Figure 2. Teachers' opinion regarding the quantity of the books included in the school library

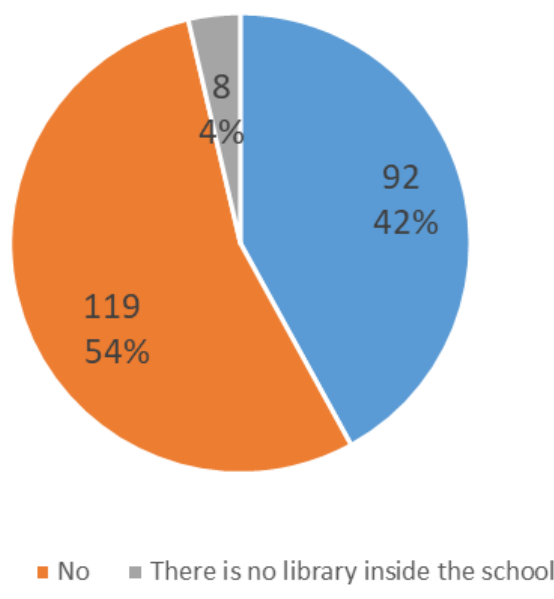

Most teachers appreciated the fact that the school library contains age-appropriate books (see figure 3) and offered a positive answer for the question: "Do you think that the books from the school library are suitable for the reading interests of your pupils?" (see figure 3 ). Teachers who chose "Another answer" mentioned that 
the library contains old or very old books and the fact that the books that appeared recently in the field of children's literature are not enough. Some teachers mentioned that they have decided to create a classroom library because there is no library inside the school.

Figure 3 . The characteristics of the books included in the school library

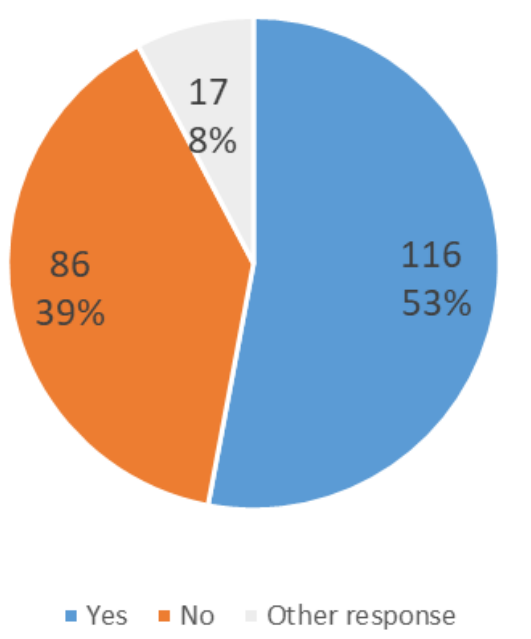

Most of the teachers appreciate that their pupils always read often or very often ( $41 \%$ of them). However, the same percentage showed that their pupils read rarely ( $41 \%$ of them). $10 \%$ of them read always, while 17 of them have selected another response variant (see figure 4 and figure 5).

Figure 4 . Frequency of the reading activities

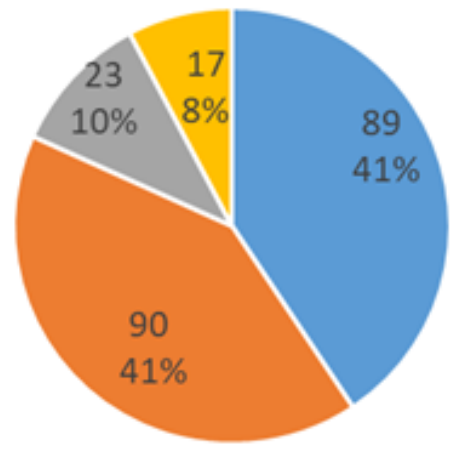

" Rarely " Often or very often " Always "Other response

Figure 5. Frequency of the reading activities. Comparative results.

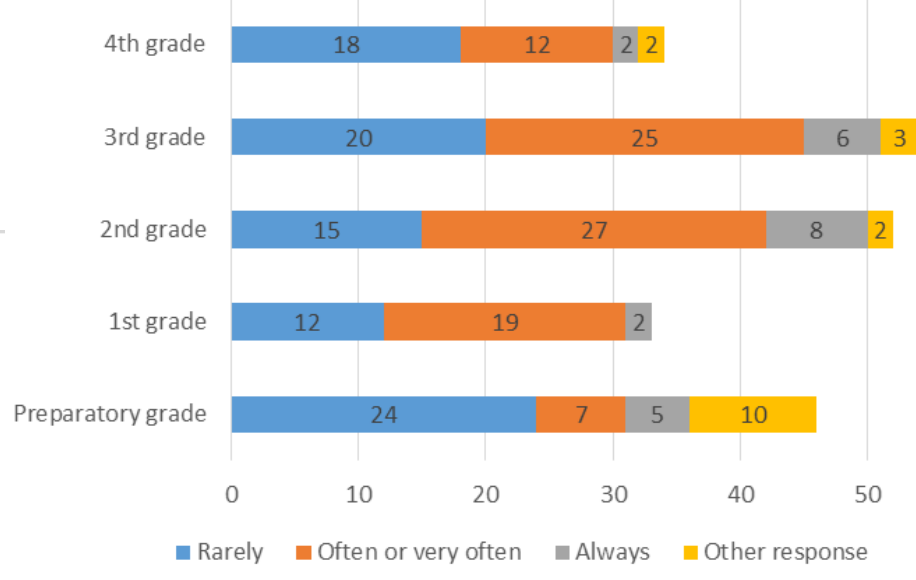

The teachers who have selected another response variant mentioned the fact that some pupils did not read with pleasure. They decide to read if the teacher asks them to carry out such activities or if the reading activities are organized in the school space. Teachers mentioned that they use various strategies to determine pupils to read. For example, they decide to choose a book that should be read in a certain amount of time by all the pupils from the class or organize a reading club in the school space or in the online environment. Most often, pupils read books that were recommended by teachers. They also mentioned that some pupils read more often, while others read rarely or extremely rarely. The reading skills of a part of the pupils enrolled in the preparatory grade were not sufficiently developed at that moment, but they carry reading activities with their parents or enjoy browsing through books.

At question number 5, "What strategies did you use to get your pupils to spend more time reading?", teachers provided answers such as those included in the table below (see table 1).

Table 1. Strategies recommended by teachers

\begin{tabular}{|c|c|c|c|c|c|}
\hline Recommended strategies & 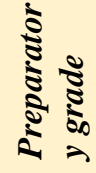 & 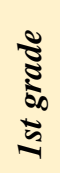 & 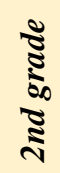 & 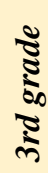 & 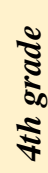 \\
\hline $\begin{array}{l}\text { - presentation of some books in } \\
\text { which the characters are close to } \\
\text { the pupils' age; }\end{array}$ & & & & $\sqrt{ }$ & \\
\hline $\begin{array}{l}\text { - studying an optional subject in } \\
\text { which reading activities are } \\
\text { encouraged; }\end{array}$ & & & & $\sqrt{ }$ & \\
\hline - organizing a reading club; & $\checkmark$ & $\checkmark$ & $\checkmark$ & $\sqrt{ }$ & $\checkmark$ \\
\hline $\begin{array}{l}\text { - arranging a mini-library / reading } \\
\text { corner in the classroom; }\end{array}$ & $\sqrt{ }$ & $\sqrt{ }$ & $\checkmark$ & $\sqrt{ }$ & $\checkmark$ \\
\hline $\begin{array}{l}\text { - organizing competitions such as } \\
\text { "Recognize the character", }\end{array}$ & $\checkmark$ & $\checkmark$ & & & \\
\hline
\end{tabular}


"Recognize the story", "Read quickly and well";

- organization of competitions, such as "Present the book",

"Reading chain", "Reading tree",

"The most active reader of the class", "Information about authors and books";

- role-reading activities;

- making panels in the classroom with information about pupils' reading preferences (eg, "Our Favorite Books," "Reading Chest," etc.);

- making portfolios entitled: "My favorite books", "Reading of the month", "The way of the book", etc .;

- awarding prizes or rewards, such as books, grades, diplomas, verbal assessments, badges with the text

"Best Reader", etc.);

- dramatization of some of the

stories preferred by pupils;

- creating contexts to present

interesting books;

- organize daily reading activities;

- stimulating pupils' curiosity to

find out the continuation or end of

a text by presenting its beginning

in an attractive way (using the

prediction method);

- creating active partnerships with

the school and the local library;

- visiting memorial houses;

- filling in reading sheets;

- watching sequences from the film

with the purpose to arouse interest

in the content of the book;

- organizing educational games

with the purpose to promote

reading activities;

- conducting role-playing games;

- organizing carnival-type

activities, in which pupils dress up

as various characters from their

favorite books;

- retelling some texts (with the

help of some suggestive images);

- watching or listening to stories;

- choosing some books that should

be read in the next period, with the

help of pupils;

- organizing visits/workshops to

bookstores;

- reading texts with guests or

family members in the school

space;
- using digital devices or

applications to improve children's

ability to read;

- making costumes worn by

characters from stories;

- discussions by which the content

of a book is compared with the

content of the movie realized based on the book;

- creating contexts through which

pupils can present to their

classmates the content of the books

they read;

- organizing literary sessions;

- organizing meetings with writers;

- creating reading journals;

- participation in book fairs;

- conducting book reviews;

- carrying out reading activities

every evening, with the help of

distance communication platforms

(A possible title for these activities could be: "A new evening, another reader").

Teachers who teach at preparatory grade have mentioned that they use books with attractive illustrations and surprising events. They also recommended frequent use of images, and drawings, showing PPT presentations, or watching videos. Primary school teachers have shown that they frequently read riddles to pupils and try to organize active learning situations. Teachers mentioned that pupils like to solve puzzles with characters or scenes from stories.

During the first grade, some teachers mentioned that they change the length and size of the texts in order to make them more accessible to pupils. Teachers also use comics. Also, parents are encouraged to read aloud for their child at least one page a day. The pupils' library must also contain age-appropriate books. Attractive books, interesting titles, and brightly colored illustrations should be included in the class library. Books that can be read by pupils are also presented to parents and children with the purpose to choose relevant titles for reading activities.

During the second, third, or fourth grade, the teachers recommend the realization of reading journals and the creation of portfolios related to the content of the books that were already read. Such portfolios could include the products of pupils' activities such as identifying beautiful expressions, making the reading map, transcribing the favorite passage, and drawing a character. Also, the usefulness of reading activities is 
outlined during the school lessons. Teachers mentioned that it is not easy to increase the pupils' interest in reading books. The personal example offered by the parents and the teachers could be important factors that influence pupils' desire to read books more frequently. Some teachers recommend age-appropriate books to pupils and give pupils a high degree of freedom in choosing the books they read. Other teachers mentioned that reading activities are mandatory for all pupils and outlined that they set the title of a book that should be read during a preset interval of time.

In the second grade, most teachers mentioned that their pupils participate each month in the reading club activities. Some teachers organize such activities more frequently, once every two weeks or even weekly. During these activities, aspects related to the books that were read by the pupils are discussed in a relaxing atmosphere. The activities of the reading club can be done outdoors when the weather is favorable. Teachers and pupils decide to participate frequently in cultural activities, such as puppet theater. Books from different fields could be used to make interdisciplinary connections. Reading aloud activities for their parents or other family members can be carried out at home.

Teachers who teach in the third grade mentioned that watching or listening to movies will be done after reading the whole text. New books are presented weekly or monthly. Teachers often recommend books from their library, starting from the premise that through the power of personal example they will be able to stimulate pupils' interest in reading texts. Organizing contexts in which pupils and parents can carry out together reading activities in the school space have beneficial effects. Thus, both parents and teachers will provide models of positive behavior for pupils. Some teachers mentioned that they often lend books from their library to pupils. Teachers considered that the involvement in campaigns/projects carried out at local or national level through which reading activities are promoted has positive effects on improving the reading habits of their pupils.

Organizing Bingo games or creating book reviews were some of the activities that were recommended by teachers who teach in the fourth grade. In various school contexts, books are recommended with the purpose to find out more information about the topics taught by the teacher. Teachers mentioned that pupils can be involved as volunteers in projects that promote reading. Some of the teachers outlined that they use to give homework that can be solved only by reading some information included in the books from the pupil's library.

The study participants advised pupils to read various books, written by Romanian authors or by writers from other countries. Authors that were most frequently recommended were: Ion Creangă, Gelu Naum, Alec Blenche, Roald Dahl, Hans Christian Andersen, Brothers Grimm, and James Orchard Halliwell-Phillipps.

\section{Discussions}

The strategies that should be applied in the family environment should be established during the teacherparent conferences, in order to increase pupils' interest in reading. Involving pupils in arranging their own library or the classroom library will stimulate their curiosity and motivation to initiate reading activities. Collaborative learning activities could be used to stimulate pupils' interest in reading books. During this type of activities should be used interesting and attractive books. Teachers can also present books from their library during school activities and talk about the content of the books that they enjoyed. Managers of each educational institution should make efforts to properly equip the school library.

\section{Conclusions}

The study revealed that primary school teachers are using a large diversity of strategies to encourage pupils to read more frequently. They make considerable and systematic efforts to include reading activities in pupils' daily schedule. The libraries from Romanian schools should be more efficiently equipped to provide pupils with the best educational opportunities.

\section{Acknowledgments}

We would like to thank all the participants for their support in conducting this study.

\section{Appendix A.}




\section{Questionnaire addressed to primary school teachers}

Dear colleagues,

Based on your teaching experience, please complete this online questionnaire. We intend to make an inventory of some reading materials, which could be recommended to primary school pupils.

1. 1. In which class do you teach?

$\ulcorner$ Preparatory grade

$\Gamma 1^{\text {st }}$ grade

$\Gamma 2^{\text {nd }}$ grade

$\left\lceil 3^{\text {rd }}\right.$ grade

$\Gamma 4^{\text {th }}$ grade

2. Do you think that the school library has enough books for primary school pupils?

$\Gamma$ Yes

$\Gamma$ No

$\ulcorner$ There is no library inside the school

3. Do you think that the books from the school library are suitable for the reading interests of your pupils?

$\Gamma$ Yes

$\Gamma$ No

$\ulcorner$ Other response

4. Most children from your class are reading:

$\ulcorner$ Rarely

$\Gamma$ Often or very often

$\Gamma$ Always

$\ulcorner$ Other response

5. What strategies did you use to determine your pupils to read more?

6. Mention one or more books that you have recommended to your pupils. Choose books that you consider valuable, age-appropriate, and attractive for your pupils.

Authors note: The authors had equal contributions to this article.

Diana-Crina Marin is currently a teacher at „Pavel Dan” Theoretical High School, in Câmpia Turzii and postdoctoral researcher at the Babeș-Bolyai University. Her research areas are aimed to find innovative modalities to consolidate the school-family partnership, considering that the school and family should be real partners regarding the children's education. She is also interested in finding the most effective teaching practices that could be successfully used in the educational process.

Mușata Bocoș is a University Professor and Ph.D. Coordinator at the Faculty of Psychology and Sciences of Education (Babeș-Bolyai University, Cluj-Napoca,
Romania). In 1997, she obtained a Ph.D. in Educational Sciences, at the Babeș-Bolyai University. Her research interests are reflected in a series of studies and articles published in important national and international journals. Her teaching activity covers several areas, such as the curriculum theory and methodology, general didactics, and educational research.

\section{References}

Chu, L., Li, P.-H., \& Yu, M.-N. (2020). The longitudinal effect of children's self-regulated learning on reading habits and well-being. International Journal of 
Educational Research, 104, 101673. Available at: https://doi.org/10.1016/j.ijer.2020.101673 (accessed at 08.01.2021).

Gong, X. (2016). Efforts to Develop the Reading Interest of the People from Children in Singapore Libraries. Science Journal of Education, 4(6), 198-205. Available at: $\quad$ https://doi.org/10.11648/j.sjedu.20160406.16 (accessed at 17.12.2020).

Henderson, L., Grové, C., Lee, F., Trainer, L., Schena, H., $\&$ Prentice, M. (2020). An evaluation of a dog-assisted reading program to support student wellbeing in primary school. Children and Youth Services Review, 118, 105449.

Available

https://doi.org/10.1016/j.childyouth.2020.105449 (accessed at 17.12.2020).

Johnston, R. S., \& Watson, J. (1997). Developing Reading, Spelling and Phonemic Awareness Skills in Primary School Children. Reading, 31(2), 38-41. Available at: https://doi.org/10.1111/1467-9345.00052 (accessed at 03.02.2021).

Kirby, J. R., Ball, A., Geier, B. K., Parrila, R., \& WadeWoolley, L. (2010). The development of reading interest and its relation to reading ability. Journal of Research in Reading, 34(3), 263-280. Available at: https://doi.org/10.1111/j.1467-9817.2010.01439.x (accessed at 03.02.2021).

Mathison, C. (1989). Stimulating and sustaining student interest in content area reading. Reading Research and Instruction, 28(3), 76-83. Available at: https://doi.org/10.1080/19388078909557977 (accessed at 08.01.2021).

Mostert, L., \& Wikan, G. (2008). Reading habits and attitudes of primary school pupils in Namibia and Norway. Education as Change, 12(1), 95-107. Available at: https://doi.org/10.1080/16823200809487197 (accessed at 08.01.2021).

Narulita Mahendra, F. F. (2020). Mobile Assisted
Language Learning: Increasing Students' Reading Interest trough E-book. Acitya Journal of Teaching \& Education, 2(1), 1-11. Available at: https://doi.org/10.30650/ajte.v2i1.272 (accessed at 08.01.2021).

Pezoa, J. P., Mendive, S., \& Strasser, K. (2019). Reading interest and family literacy practices from prekindergarten to kindergarten: Contributions from a cross-lagged analysis. Early Childhood Research Quarterly, 47, 284-295. Available at: https://doi.org/10.1016/j.ecresq.2018.12.014 (accessed at 28.01.2021).

Sánchez, M., Campillo, M., \& Díaz, M. P. (2020). Reading mentors in primary education. Lessons learned from piloting an intergenerational school model. International Journal of Educational Research, 100, 101539. Available at: https://doi.org/10.1016/j.ijer.2020.101539 (accessed at 30.01.2021).

Segundo Marcos, R. I., López Fernández, V., Daza González, M. T., \& Phillips-Silver, J. (2020). Promoting children's creative thinking through reading and writing in a cooperative learning classroom. Thinking Skills and Creativity, 36, 100663. Available at: https://doi.org/10.1016/j.tsc.2020.100663 (accessed at 30.01.2021).

Uusen, A., \& Müürsepp, M. (2012). Gender Differences in Reading Habits Among Boys and Girls of Basic School in Estonia. Procedia - Social and Behavioral Sciences, 69, 1795-1804. Available at: https://doi.org/10.1016/j.sbspro.2012.12.129 (accessed at 07.02.2021).

Zivan, M., \& Horowitz-Kraus, T. (2020). Parent-child joint reading is related to an increased fixation time on print during storytelling among preschool children. Brain and Cognition, 143, 105596. Available at: https://doi.org/10.1016/j.bandc.2020.105596 (accessed at 07.02.2021). 